\title{
THE EFFECT OF CONSUMERS' ATTITUDES TOWARD THE MOBILE ADVERTISING ON IMPULSE BUYING BEHAVIOR
}

DOI: 10.17261/Pressacademia.2018.863

PAP- V.7-2018(16)-p.101-108

Selda Basaran Alagoz ${ }^{1}$, Esin Ceylan ${ }^{2}$

${ }^{1}$ Necmettin Erbakan University, Konya, Turkey.

sbalagoz@konya.edu.tr, ORCID: 0000-0002-4615-5337

${ }^{2}$ Selcuk University, Konya, Turkey.

esinceylan@selcuk.edu.tr, ORCID: 0000-0002-4566-0542

To cite this document

Alagoz, B. S., Ceylan, E. (2018). The effect of consumers' attitudes toward the mobile advertising on impulse buying behavior. PressAcademia Procedia (PAP), V.7, p.101-108.

Permemant link to this document: http://doi.org/10.17261/Pressacademia.2018.863

Copyright: Published by PressAcademia and limited licenced re-use rights only.

\section{ABSTRACT}

Purpose- As result of expansion of the using mobile phone depending on the development of technology, businesses make promotions of products or services under the name of mobile advertising by sending messages to consumers' mobile phones. SMS advertising is often used in mobile ads. One of the most important advantages of the mobile ads that businesses prefer is to reach directly to more consumers in less time. After consumers informed about related products or services with the mobile advertising message, they may also show impulse buying behavior. The aim of this research is to determine the effect of consumers' attitudes, who are using mobile phone, toward the mobile advertising on impulse buying behavior.

Methodology- The questionnaire prepared for the research was applied to 395 people. Correlation and regression analysis were applied to analyze the attitudes towards mobile ads and impulse buying behavior.

Findings- As a result of research analysis, participants' attitudes towards mobile ads have been found as positive and they are tend to impulse buying.

Conclusion- Moreover, it concluded that there is an effect of consumers' attitudes toward the mobile advertising on impulse buying behavior.

Keywords: Mobile advertising, consumer attitude, impulse buying behaviour.

JEL Codes: L96, M31, M37

\section{TÜKETICILERIN MOBiL REKLAMLARA KARŞI TUTUMLARININ ANLIK SATIN ALMA DAVRANIŞINA ETKisi}

\section{ÖZET}

Amaç- Teknolojinin gelişmesine bağıı olarak mobil telefon kullanımının gün geçtikçe yaygınlaşması sonucu işletmeler ürün veya hizmet tanıtımlarını mobil reklam adı altında tüketicilerin cep telefonlarına gönderilen mesajlarla yapmaktadırlar. Mobil reklamların içerisinde genellikle SMS reklamları kullanılmaktadır. İşletmelerin mobil reklamı tercih etmesindeki en önemli avantajlardan biri daha kısa sürede daha çok tüketiciye doğrudan ulaşabilmektir. Mobil reklam mesajıyla tüketiciler ilgili ürün veya hizmet hakkında bilgilendirildikten sonra anlık olarak satın alma davranışı da gösterebilmektedirler. Bu çalışmanın amacı, mobil telefon kullanan tüketicilerin mobil reklamlara karşı tutumlarının anlık satın alma davranışı üzerine etkisini belirlemektir.

Yöntem- Çalışmaya yönelik olarak hazırlanan anket 395 kişiye uygulanmıştır. Mobil reklamlara yönelik tutum ve anlık satın alma davranışını ölçmek için korelasyon ve regresyon analizleri yapılmıştır.

Bulgular- Araştırma sonucunda katılımcıların mobil reklamlara karşı tutumlarının olumlu ve anlık satın almaya eğilimli oldukları tespit edilmiştir.

Sonuç- Ayrıca, tüketicilerin mobil reklamlara yönelik tutumların anlık satın alma davranışı üzerine etkisi olduğu sonucuna da varılmıştır

Anahtar Kelimeler: Mobil reklamcilik, tüketici tutumu, anlik satin alma.

JEL Kodları: L96, M31, M37 


\section{GiRiş}

Son yıllarda mobil iletişim teknolojisinin gelişmesiyle birlikte pazarlama alanında da değişiklikler yaşanmaya başlamıştır. Rekabetin artmasıyla birlikte işletmeler hedef tüketici grubuna en hızlı bir şekilde ulaşmak ve onları ürün ve hizmetleri hakkında bilgilendirmek istemektedirler. Bu bağlamda işletmeler daha kısa sürede daha çok tüketiciye ulaşmak için mobil reklamlar pazarlamada etkili bir iletişim kanalını oluşturmaktadır. Mobil pazarlama ekseninde gerçekleşen mobil reklamlar işletmeler açısından hızlı gelişen bir trend göstermektedir.

İşletmeler ürün veya hizmet satışı yapıp kârlılıklarını ve buna bağı olarak pazar paylarını arttırmak istemektedirler. Bunun için de temel amaç daha çok tüketicinin ürün veya hizmetler hakkında bilgi sahibi olup satın almalarını sağlamaktır. Bu amaçla cep telefonlarına gönderilen mobil reklam mesajlarının içeriğinin tüketicide ürün veya hizmeti satın alma isteği uyandırması sağlanmaktadır. Planlanmamış olarak tüketicinin zihninde oluşan satın alma isteği "anlık satın alma” kavramıyla açıklanabilmektedir.

Tüketicilerin mobil reklamlara yönelik tutumları işletmelerin reklam etkinliği açısından önem arz etmektedir. Kişiye özel olan cep telefonlarına sürekli ve izinsiz olarak gönderilen reklam mesajları tüketiciler tarafından rahatsız edici olarak algılanmaktadır (Çakır vd., 2010:28). Tüketicilerin özel hayatına müdahale, ilgisizlik ve mesajların uzunluğu, zamansız olması ve aşırı bilgi yüklenmiş olması da mobil reklam mesajlarının dezavantajlarını oluşturmaktadır (Trappey ve Woodside, 2005: 382).

Bilgi Teknolojileri ve İletişim Kurumu'nun 2017 yılı 3. Çeyrek Pazar Verileri Raporu'na göre Türkiye'de 77.882 .845 milyon mobil abone bulunmaktadır (www.btk.gov.tr). Mobil abone sayısının artması işletmeler için de mobil pazarlamayı cazip hale getirmektedir. Nielsan Türkiye tarafından gerçekleştirilen 2016 Türkiye Mobil Reklam Harcama Araştırması Raporu'na göre yıl içerisinde mobil reklam yatırımları 122 milyon € olduğu açıklanmıştır (www.mmaturkey.org). Açıklanan verilerden hareketle Türkiye'de mobil telefon kullanan tüketicilere SMS reklamlarına karşı tutumlarının anlık satın alma davranışını belirlemek için bu çalışma yapılmıştır.

\section{LITERATÜR INCELEMESI}

\subsection{Mobil Reklamlar ve Tutum}

Günlük hayatın vazgeçilmez bir unsuru haline gelen mobil cihazlar son yıllarda yaşanan teknolojik gelişmelerin bir ürünüdür. İşletmeler mevcut ve potansiyel tüketicilerine bu araçlar vasıtasıyla daha kısa sürede ulaşabilmektedir. Mobil cihazların yaygın olarak kullanılması ise pazarlamada yeni bir alanın gelişmesine de imkân sağlamıştır. Bu alan mobile pazarlama olarak ifade edilmektedir.

Amerikan Mobil Pazarlama Birliği (MMA), mobil pazarlamayı "reklam ve satış promosyon aktivitelerinin, mobil kanallar yoluyla müşteri ve davranışlarını hedef alan bir pazarlama türü" olarak tanımlamaktadır (Yüce vd., 2012:182).

Kablosuz bir kitle iletişim aracı olarak kullanılan mobil pazarlama zaman ve yer ile beraber tüketicilere mal, hizmet ve fikirleri geliştiren konuma duyarlı, kişiselleştirilmiş bilgi sunmakta, bu şekilde tüm paydaşlar yararlanmaktadırlar (Scharl vd., 2005:165). Tüketiciye ulaşmak için uzaktan ve kablosuz erişime uygun olan cep telefonları, cep bilgisayarları ve bunlara benzer araçlar yoluyla mevcut ve potansiyel tüketiciye ulaşacak kurum, ürün, hizmet, fikir, eylem ve kişilere yönelik pazarlama çalışmalarının yapılması da mobil pazarlamayı açıklamaktadır. Ayrıca tüketiciler bu kanallar aracılı̆̆ılla katılımda bulunmakla birlikte ürün ve marka ile de etkileşime de geçmektedir (Arslan ve Arslan, 2012:25). Mobil telefonlar birçok nedenden dolayı pazarlamada çekici bir unsur olarak görülmektedir. Bu nedenler tüketicilerin mobil telefonları her zaman her yerde yanlarında bulundurmaları ve çoğu zaman açık tutmaları, tüketicilerle birebir iletişim kurulması, mesajların hızı ve kolay bir şekilde yanıtlanması veya mesajların depolanıp daha sonra cevap verilmesi, tüketicilerle çeşitli araçlarla sesli ve görüntülü iletişim kurma imkânı sağlaması olarak sıralanabilir. Günümüzde mobil uygulamalar da tüketicilere ulaşmada, ürün ve hizmetler hakkında bilgilendirme etkili olmakla birlikte tüketicilerin etkinleşmesini sağlayan geniş bir iletişim yelpazesine yol açmaktadır (Yuan ve Cheng, 2004:462). Reklam aracı olarak mobil telefonların kullanılmasıyla birlikte mobil reklamcılık da mobil pazarlama faaliyetleri arasında yer almaktadır (Altuğ ve Yürük, 2013:13).

Mobil reklam, tüketicilere ürün ve hizmetlerin tanıtımının yapılması amacıyla reklam mesajlarını iletmek için interaktif kablosuz kitle iletişim araçlarının (cep telefonları ve çağıı cihazları, telsiz telefonlar, cep bilgisayarları, alııı ve verici radyo cihazları, Küresel Konumlama Sistemi (GPS), kablosuz ağ sistemi vb.) kullanımıdır (Haghirian ve Madlberger, 2006:2). Günümüzde mobil reklamlar; mobil internet, mobil mesajlaşma, mobil uygulamalar, mobil video ve tv aracılığıla yapılmaktadır (Durucasu ve Ersoy, 2016:3). SMS reklam pazarının da hızla büyümesindeki en önemli neden bütün cep telefonlarının mesaj alma ve gönderme özelliğinin bulunmasıdır (Michael ve Salter, 2006:9).Bu özellik işletmelerin de SMS reklamlarını tercih etmesinde önemli rol oynamaktadır.

Mobil reklam yapacak olan işletmelerin göz önünde bulundurması gereken bazı engeller de bulunmaktadır. Bu engelleri mobil internet tarayııılarının yetersiz olması, mobil cihazların ekran genişliği ve tuş takımları, geleneksel alışveriş kültürü, mobil cihazların konum belirlemede eksikliği, internete göre daha yavaş veri alışverişi sağlaması, bilgi ve tecrübe eksikliği ve güvenliğin yetersiz olması gibi özetlemek mümkündür (Arslan ve Arslan, 2012:70-71).

SMS reklamlarının uygun içerikle etkin bir şekilde hazırlanması tüketicilerin satın alma davranışını etkilemede önemli bir unsur olarak görülmektedir (Arslan ve Arslan, 2012:71). Bu bağlamda işletmeler tüketicilere ürün veya hizmetlerinin tanıtımını yapmak amacıyla göndermiş oldukları mesajların içeriğine dikkat etmelidirler.

Tüketiciler gönderilen mesajın içeriğine göre mobil reklamlara ve reklam yapan işletmeye karşı tutum geliştirmektedirler (Altuğ ve Yürük, 2013:14). Mobil reklam içeriğinin özellikleri; "eğlendirme", "bilgilendirme", "sinirlendirme", "kişiselleştirme" ve "güvenilirlik" tir (Arslan ve Dursun, 2015:11).

Tutumlar ilk kez 1960 yılında Rosenberg ve Hovland tarafından incelenmeye başlanmış ve sınıflandırılmıştır (Çöllü ve Öztürk, 2006:375). Tutumlar, "nesneler, insanlar ya da olaylar hakkında- olumlu ya da olumsuz- değerlendirme içeren ifadeler"dir (Robbins ve Judge, 2012:72). 
Tutumlar temel olarak bir şeylere karşı yatkınlığımız olup bir şeyden hoşlanıp hoşlanmadığımızı göstermektedir (Severin ve Tankard, 2001:151).

Literatürde mobil reklamlara yönelik tutumların incelendiği pek çok çalışma yapılmıştır. Bu çalışmalardan bazıları şunlardır.

Tsang vd., (2004)'in tüketicilerin mobil reklamlara yönelik tutumlarını belirlemek amacıyla yaptıkları çalışmada tüketicilerin "bilgilendirme, eğlendirme ve güvenilirlik" ile mobil reklam yönelik olumlu tutum, sinirlendirme ile olumsuz tutum içinde olduklarını tespit etmişlerdir. Peng (2006), Çin'de yaşayan tüketicilerin mobil reklama olan tutumları üzerine yapmış olduğu çalışmada tutumları en fazla etkileyen unsurun "gönderilen reklamın güvenilirliği" olduğunu tespit etmiştir. Xu vd. (2008)'nin yaptıkları çalışmada ise tüketicilerin mobil reklama yönelik tutumunu etkileyen en önemli faktörlerin "eğlendirme, güvenilirlik ve kişisellik" olduğunu tespit etmişlerdir.

Suher ve İspir (2009)'in Türkiye' de SMS reklamlarının tüketici tutumlarını etkileyen faktörler üzerine yapmış oldukları çalışmada , "rahatsız edicilik" faktörünün SMS reklamlarına yönelik tutumları etkileyen en önemli faktör olduğunu tespit etmişlerdir. Usta (2009)'un üniversite öğrencilerinin mobil reklamcılığa karşı tutumları belirlemek üzere yapmış olduğu çalışmada, öğrencilerin kısa mesaj reklamlarını eğlendirici, bilgilendirici ve güvenilir bulmadıkları ve hatta sinir bozucu olduklarını düşündükleri ifade edilmiştir. Üniversite öğrencilerinin kısa mesaj reklamlarına yönelik tutumlarının olumsuz olduğu sonucuna varılmıştır. Boz ve Karakaş (2014)'ın Türkiye'de tüketicilerin mobil reklama yönelik tutumlarını belirlemek için yaptıkları çalışmada tüketicilerin mobil reklama yönelik tutumlarının olumsuz olduğu sonucuna varılmıştır. Ancak Arslan ve Dursun (2015)'in Türk tüketicilerinin mobil reklamlara yönelik tutumlarını belirlemek için yaptıkları çalışmada ise mesaj içeriğini oluşturan boyutlardan eğlendirme, bilgilendirme, güvenilirlik ve kişiselleştirme ile mobil reklamlara yönelik tutum arasında pozitif bir ilişki; sinirlendirme ile mobil reklamlara yönelik tutum arasında negatif bir ilişki olduğu tespit edilmiştir. Ayrıca cinsiyetin de mobil reklamlara yönelik tutumu etkilediği sonucuna varılmıştır.

Bireylerin sahip oldukları tutumlar satın alma kararlarını doğrudan etkilemektedir. Buna bağlı olarak hedef pazar bölümlerindeki tüketicilerin tutumları ölçüp değerlendirebilir. Pazarlamacılar da tüketicilerin satın alma davranışlarını tahmin ederek başarı sağlayabilirlerler (İslamoğlu ve Altunışık, 2010:170).

\subsection{Anlık Satın Alma}

Tüketiciler için karar alma sürecinden sonra ki aşamassatın alma davranışıdır (Altunışık vd., 2002:72). Satın alma davranışı, bireylerin ürün ve hizmetleri satın alma sürecini içeren davranışlarıdır (Pride ve Ferrell, 2000:195).

Satın alma, "bir ürün veya hizmetin genellikle belirli bir amaca hizmet etmesi için bazen de bir amaca hizmet etmese bile haz duygusu sonucunda karşılığında bir bedel verilerek aidiyet altına alınması"dır (Akt:Yalman, 2014:22). Satın almaya ilişkin literatür incelendiğinde satın alma davranışlarının planlanan ve planlanmayan satın alma olarak üzere ikiye ayrıldığı görülmektedir (Erdem vd., 2015:60). Beatty ve Ferrel çalışmalarında plansız ve anlık satın almanın aynı anlama geldiğini belirtmişlerdir (Beatty ve Ferrell, 1998:170).

Anlık satın almayı, Rook (1987) tüketicinin aniden ve kuvvetli satın alma isteği, Rook ve Horch (1985) ihtiyaç olamayan ve herhangi bir fayda sağlamamasına rağmen yapılan plansız satın alımlar, Piron (1991) bir uyarıcı sonucu satın alma kararının verildiği yerde ve zamanda yapılan satın alımlar, Beatty ve Ferrel (1998) tüketici bir ürünü gördüğünde onu satın almaya sebep olan ve ansızın oluşan dürtüye göre satın alımlar olarak tanımlamaktadırlar (Torlak ve Tiltay, 2010: 407). Anlık satın almayı etkileyen faktörler ise; duygular, hedonik nedenler, alışveriş merkezi, mağaza atmosferi, cinsiyet, yaş vb. dir (Virvilaite vd., 2011:1330-1331)

Bayley ve Nancarrow (1998), çalışmalarında anlık satın almayı yüksek fonksiyonel fayda ve yüksek sembolik fayda olmak 2 unsurlu düzlemde göstermişlerdir.

\section{Şekil 1: Anlık Satın Almayı Gösteren íki Boyutlu Harita}

Yüksek Fonksiyonel Fayda

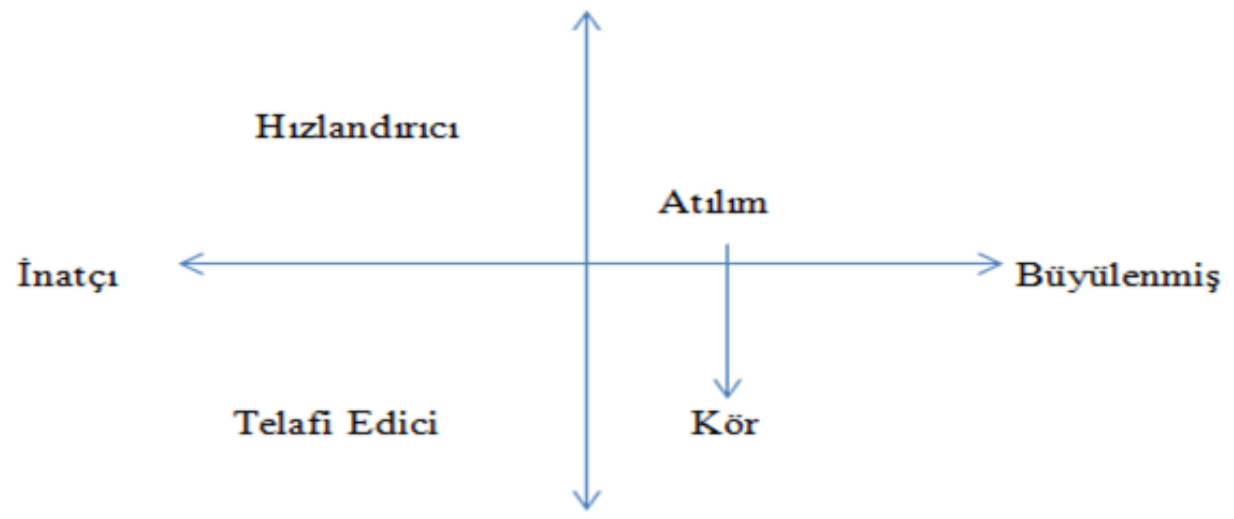

Yüksek Sembolik Fayda

Kaynak: Bayley ve Nancarrow, 1998:112. 
Anlık satın almayı gösteren iki boyutlu haritaya göre anlık satın alma dört gruba ayrılmaktadır (Bayley ve Nancarrow, 1998: 110-111).

Hızlandırıcı Dürtü: Tüketici gelecekte ihtiyaç duyacağını düşündüğü ürünleri gördüğünde stoklamak için satın alır.

Telafi Edici Dürtü: Zorlu bir görevi başarmanın ödülü olarak ruh halini iyileştirici veya satın almada ki başarısızlıktan dolayı özsaygıyı korumak için telafinin yapılmasıdır.

Atılım Dürtüsü: Geçmişten gelen memnuniyetsizliği ve anlaşmazlığı çözmek için harekete geçen dürtüdür. Bu dürtü sonucunda tüketici hayatını değiştirebilecek yüksek harcamalar yapabilir.

Kör Dürtü: Herhangi bir işlev veya maliyet kısıtlamasından bağımsız olarak, ürün tarafından kör edilme hissidir. Fonksiyonel değildir.

Tüketicilerin günlük hayatta karşılaştıkları birçok etken onları satın almaya yönlendirmektedir. Bu bağlamda işletmelerin ürün veya hizmetleri ile ilgili tüketicilere göndermiş olduğu mobil reklamların anlık satın alma davranışı üzerinde ki etkisi belirlenmeye çalışımaktadır.

\section{VERI VE YÖNTEM}

Türkiye'de yaşayan 18 yaşından büyük mobil telefon kullanan tüketiciler araştırmanın evrenini oluşturmaktadır. Araştırma, evrendeki her bireyin "eşit" ve "bağımsız" seçilme şansına sahip olan basit tesadüfi örnekleme yöntemiyle (Altunışık vd., 2010:137) erişilebilen 395 tüketiciden oluşmaktadır. Araştırmanın amacına ulaşmak için mobil reklamlara yönelik tutum ve anlık satın alma davranışlarını belirlemek için yüz yüze ve online anket yöntemi uygulanmıştır. Anket formu üç ana bölümden oluşmaktadır. Birinci bölüm tüketicilerin demografik özellikleri incelemek üzere oluşturulmuştur. İkinci bölümde (Tsang vd., 2004) Mobil Reklamlara Karşı Tutum ölçeğine ilişsin ifadeler bulunmaktadır. Üçüncü bölümde ise (Rook ve Fisher, 1995) Anlık Satın Alma ölçeğine ilişkin ifadeler yer almaktadır. Ölçek soruları 5'li Likert ölçeğine göre değerlendirilmiştir.

Ölçeklerin Cronbach Alpha değerleri incelendiğinde Mobil Reklamlara Yönelik Tutum ölçeği 0,785 oranında güvenilir iken Anlık Satın Alma Davranışı ölçeğinin 0,811 oranında güvenilir olduğu tespit edilmiştir. Elde edilen sonuçlar ölçeklerin güvenilirliğini desteklemektedir (İslamoğlu ve Alnıç̧ı, 2014: 283; Kalaycı, 2010:405).

\section{BULGULAR}

Ankete katılan tüketicilerin demografik özellikleri, çalışmanın amacına uygun olarak tespit edilen ölçek soruları ve hipotezleri test etmek amacıyla yapılan çalışmalar aşağıda yer almaktadır

Tablo 1'de ankete katılan mobil telefon kullanan tüketicilerin demografik değişkenlerine ilişkin tanımlayıcı istatistiki verileri yer almaktadır.

\section{Tablo 1: Demografik Özellikler}

\begin{tabular}{|c|c|c|c|c|c|}
\hline Değişken & Sıklık (n) & Yüzde (\%) & Değişken & Sıklık (n) & Yüzde (\%) \\
\hline \multicolumn{3}{|l|}{ Cinsiyet } & \multicolumn{3}{|l|}{ Medeni Hal } \\
\hline Kadın & 242 & 61,3 & Evli & 157 & 39,7 \\
\hline Erkek & 153 & 38,7 & Bekar & 238 & 60,3 \\
\hline \multicolumn{3}{|l|}{ Yaş } & \multicolumn{3}{|l|}{ Meslek } \\
\hline $18-25$ yaş & 132 & 33,7 & Öğrenci & 117 & 29,6 \\
\hline 26-35 yaş & 97 & 24,6 & Devlet Memuru & 101 & 25,6 \\
\hline $36-45$ yaş & 92 & 23,3 & Özel Sektör Çalışanı & 86 & 21,8 \\
\hline 46-55 yaş & 48 & 12,2 & Serbest Meslek & 51 & 12,9 \\
\hline $56-65$ yaş & 21 & 5,3 & Emekli & 5 & 1,3 \\
\hline 66 yaş ve üzeri & 5 & 1,3 & Çalışmıyor & 35 & 8,9 \\
\hline \multicolumn{3}{|l|}{ Gelir Durumu } & \multicolumn{3}{|l|}{ Eğitim Düzeyi } \\
\hline $0-1603 も$ & 182 & 46,1 & İlköğretim ve altı & 30 & 7,6 \\
\hline 1604-3000 も & 83 & 21,0 & Lise Mezunu & 174 & 44,1 \\
\hline 3001-4000も & 51 & 12,9 & Üniversite Mezunu & 124 & 31,4 \\
\hline 4001-5000も & 47 & 11,9 & Yüksek Lisans/Doktora & 67 & 17,0 \\
\hline 5001も ve üzeri & 32 & 8,1 & Toplam & 395 & 100,0 \\
\hline
\end{tabular}

Araştırmaya katılan bireylerin demografik özelliklerine bakıldığında katılımcıların \%1,3,'ü kadın, \%38,7'si erkek tüketicilerden oluşmakta olup bunlardan $\% 39,7^{\prime}$ si evli ve \%60,3'ü bekardır. Tüketicilerin \%33,7'i 18-25 yaş, \%24,6'sı 26-35 yaş, \% 23,3'ü 36-45 yaş, \%12,2'si 46-55 yaş, \%5,3'ü 56-65 yaş ve \% 1,3'ü 66 yaş ve üzerindedir. Ankete katılan tüketicilerin \%29,6'sı öğrenci, \%25,6'sı devlet memuru, \%21,8'i özel sektör çalışanı, \%12,9'u serbest meslek, \%1,3'ü emekli ve \%8,9'u çalışmayan kesimi temsil etmektedir. Tüketicilerin \%46,1'i 0-1603も, \%21'i 1604-3000も,\%12,9’u 3001-4000も, \%11,9’u 4001-5000も ve \%8,1'i 5001も ve üzeri gelire sahip olduğu görülmektedir. Katılımcıların \%7,6’sı ilköğretim ve altı, \%44,1'i lise mezunu, \%31,4'ü üniversite mezunu ve \%17'si yüksek lisans /doktora eğitim düzeyine sahiptir.

Tüketicilerin cinsiyet ve medeni durum değişkenlerinin mobil reklamlara karşı tutumlarını test etmek amacıyla T-Test yapılmıştır. Analiz sonuçları Tablo 2'de gösterilmiştir. 
Tablo 2: T-Test Sonuçları

\begin{tabular}{|l|l|l|l|l|}
\hline Cinsiyet & N & $\overline{\mathbf{x}}$ & Standart Sapma & $\mathbf{p}$ \\
\hline Kadın & 242 & 3,25 & 0,56 & \multirow{2}{*}{0,02} \\
\hline Erkek & 153 & 3,23 & 0,63 & $\mathbf{p}$ \\
\hline Medeni Durum & $\mathbf{N}$ & $\overline{\mathbf{x}}$ & Standart Sapma & \multirow{2}{*}{0,22} \\
\hline Evli & 157 & 3,32 & 0,63 & \\
\hline Bekar & 238 & 3,19 & 0,56 & \\
\hline
\end{tabular}

Analiz sonucunda katılımcıların cinsiyetleri ile mobil reklamlara karşı tutumun farklılık gösterdiği sonucuna varılmıştır ( $p<0,05$ ). Ancak medeni durum ile mobil reklamlara karşı tutum arasında anllamlı bir ilişki bulunmamaktadır.

Tüketicilerin yaş, gelir durumu, eğitim düzeyi ve meslek ile mobil reklamlara karşı tutum arasında ki ilişkiyi belirlemek için Anova Analizi yapılmıştır. Analiz sonuçları Tablo 3'te gösterilmiştir.

\section{Tablo 3: Anova Analizi Sonuçları}

\begin{tabular}{|c|c|c|c|c|}
\hline Yaş & $\mathbf{N}$ & $\overline{\mathbf{x}}$ & Standart Sapma & $\mathbf{p}$ \\
\hline $18-25$ yaş & 132 & 3,15 & 0,58 & \multirow{6}{*}{0,00} \\
\hline 26-35 yaş & 97 & 3,26 & 0,55 & \\
\hline 36-45 yaş & 92 & 3,28 & 0,63 & \\
\hline $46-55$ yaş & 48 & 3,28 & 0,58 & \\
\hline 56-65 yaş & 21 & 3,37 & 0,60 & \\
\hline 65 yaş üzeri & 5 & 3,95 & 0,16 & \\
\hline Gelir Durumu & $\mathbf{N}$ & $\overline{\mathbf{x}}$ & Standart Sapma & $\mathbf{p}$ \\
\hline $0-1603 \mathrm{TL}$ & 182 & 3,16 & 0,56 & \multirow{5}{*}{0,09} \\
\hline 1604-3206 TL & 83 & 3,28 & 0,60 & \\
\hline $3207-4000 \mathrm{TL}$ & 51 & 3,44 & 0,54 & \\
\hline 4001-5000 TL & 47 & 3,20 & 0,61 & \\
\hline 5001 TL ve üzeri & 32 & 3,38 & 0,72 & \\
\hline Eğitim Düzeyi & $\mathbf{N}$ & $\overline{\mathbf{x}}$ & Standart Sapma & $\mathbf{p}$ \\
\hline İlköğretim ve altı & 30 & 3,56 & 0,57 & \multirow{4}{*}{0,00} \\
\hline Lise Mezunu & 174 & 3,18 & 0,56 & \\
\hline Üniversite Mezunu & 124 & 3,20 & 0,60 & \\
\hline Yüksek Lisans/Doktora & 67 & 3,35 & 0,62 & \\
\hline Meslek & $\mathbf{N}$ & $\overline{\mathbf{x}}$ & Standart Sapma & $\mathbf{p}$ \\
\hline Öğrenci & 117 & 3,07 & 0,55 & \multirow{6}{*}{0,04} \\
\hline Devlet Memuru & 101 & 3,28 & 0,60 & \\
\hline Özel Sektör Çalışanı & 86 & 3,33 & 0,62 & \\
\hline Serbest Meslek & 51 & 3,28 & 0,51 & \\
\hline Emekli & 5 & 4,05 & 0,14 & \\
\hline Çalışmıyor & 35 & 3,35 & 0,62 & \\
\hline
\end{tabular}

Tabo 3'te analiz sonuçlarına bakıldığında tüketicilerin yaş grupları ve eğitim düzeyleri ile mobil reklamlara karşı tutum arasında farklılık olduğu görülmektedir $(p<0,05)$. Bu farklılı̆ın hangi gruplardan kaynaklandığını belirlemek için Post Hoc testleri uygulanmıştır. 55 yaş ve üzeri tüketiciler ile diğer yaş grupları arasında farklııı bulunmaktadır. Tüeticilerin yaşları ilerledikçe mobil reklamlara karşı olan tutum olumsuz olmaktadır. Tüketicilerin eğitim düzeyinde ki farklılı̆̆a bakıldığında ise illköğretim ve altı eğitim düzeyine sahip olanlar ile diğer gruplar arasında farklııı bulunmaktadır. Eğitim seviyesi düştükçe mobil reklamlara karşı olumlu tutum azalmaktadır.

Araştırma hipotezlerinin test edilmesi amacıyla öncelikli olarak ölçekteki soruların normal dağılım gösterip göstermediği test edilmiştir. Kolmogrov-Smirnov testi sonuçlarına göre verilerin normal dağılım gösterdiği tespit edilmiştir $(p>0,05)$.

H1:Mobil reklamlara yönelik tutum ve anlık satın alma davranışı arasında pozitif ve istatistiksel açıdan anlamlı bir ilişki vardır.

Değişkenler arasındaki ilişkiyi tespit etmek amacıyla Pearson Korelasyon Analizi uygulanmıştır. Analize ilişkin sonuçlar aşağıda Tablo 4'te sunulmuştur. 
Tablo 4: Korelasyon Matrisi

\begin{tabular}{|l|l|l|}
\hline & Mobil Reklamlara Yönelik Tutum & Anlık Satın Alma \\
\hline Mobil Reklamlara Yönelik Tutum & $\mathbf{1}$ & \\
\hline Anlık satın alma &, $655^{* *}$ & $\mathbf{1}$ \\
\hline Not: ${ }^{* *} p<0.05$ &
\end{tabular}

Korelasyon matris tablosu incelendiğinde anlık satın alma ve mobil reklamlara yönelik tutum arasında pozitif bir ilişki olduğu görülmektedir $(0,655)$. Bu doğrultuda Mobil reklamlara yönelik tutum ve anlık satın alma davranışı arasında pozitif ve istatistiksel açıdan anlamlı bir ilişki vardır" hipotezi kabul edilmiştir. Tüketicilerin mobil reklamlara karşı olumlu veya olumsuz tutumları anlık satın alma davranışlarını etkilemektedir.

H2: Mobil reklamlara yönelik tutumların anlık satın alma davranışı üzerine etkisi vardır.

Değişkenler arasındaki ilişkiden hareketle mobil reklamlara yönelik tutum ile anlık satın alma davranışı arasındaki nedensellik ilişkisi aşağıda Tablo 5'te Regresyon Analizi tablosunda incelenmiştir.

Tablo 5: Basit Doğrusal Regresyon Analizi: Anlık Satın Alma

\begin{tabular}{|c|c|c|c|c|c|c|c|}
\hline $\begin{array}{l}\text { Bağımlı } \\
\text { Değişken }\end{array}$ & $\mathrm{A} d j_{x} R^{2}$ & $\begin{array}{l}\text { Bağımsız } \\
\text { Değişken }\end{array}$ & B & Std. Hata & $\mathbf{T}$ & $\mathbf{F}$ & $\mathbf{p}$ \\
\hline \multirow{2}{*}{$\begin{array}{l}\text { Anlık Satın } \\
\text { Alma }\end{array}$} & \multirow[b]{2}{*}{,427 } & Sabit Terim &,- 014 & ,189 &,- 076 & \multirow[b]{2}{*}{$293,253^{*}$} & 940 \\
\hline & & $\begin{array}{l}\text { Mobil Reklamlara } \\
\text { Yönelik Tutum }\end{array}$ & 979 & ,057 & 17,125 & & ,000 \\
\hline
\end{tabular}

Not: ${ }^{*} p<.05,{ }^{*} p<.01$

Regresyon analizi sonuçlarına göre $A R^{2}$ yani açıklanan varyansın yüzdesi ve $\mathrm{F}$ yani Regresyon modelinin anlamlılık yüzdesi tüketicilerin anlık satın alma davranışının mobil reklamlara yönelik tutumları ile açıklanabileceğini göstermektedir. Bir başka ifade ile değişkenlerin birbirleri üzerindeki etkisi $p=0,000$ ve $F=293,253$ düzeyinde anlamlıdır. Bu bağlamda öne sürülen mobil reklamlara yönelik tutumların anlık satın alma davranışı üzerine etkisi vardır şeklinde ileri sürülen $\mathrm{H} 2$ kabul edilmiştir.

Regresyon analizi sonuçlarına göre $A R^{2}$ yani açıklanan varyansın yüzdesi ve $\mathrm{F}$ yani regresyon modelinin anlamlılık yüzdesi tüketicilerin anlık satın alma davranışının mobil reklamlara yönelik tutumları ile açıklanabileceğini göstermektedir.

\section{SONUÇ}

Iş̧letmeler kârlılıklarını artırmak amacıyla ürün ve hizmetlerin tanıtımını yapmak için tüketici kitlesini genişletmek isterler. Teknolojik gelişmeler sayesinde işletmeler kısa bir zaman içerisinde çok fazla tüketiciye ulaşma imkânına kavuşmuştur. Tüketicileri ürün ve hizmetler hakkında bilgilendirmek amacıyla çeşitli mobil iletişim araçları kullanılabilmektedir. İşletmelerin en yaygın olarak kullandıkları ise mobil telefonlara gönderdikleri SMS reklamlarıdır. Tüketicilere gönderilen mesajların içeriği, uzunluğu ve gönderme sıklığı önemlidir. Aksi takdirde tüketiciler işletmeye olumsuz tutum sergilerler ve bu da onların satın alma kararlarını etkiler. Tüketiciler, kendilerine gelen mobil reklam mesajlarıyla o an ihtiyacı olmasına rağmen gelecekte ihtiyaç duyabileceğini düşünüp satın alma kararı verebilmektedir.

Son yıllarda mobil pazarlama etkinliğinin artmasıyla birlikte farklı ülkelerde de bu alanda pek çok çalışma yapılmıştır. Tsang vd., (2004)'nin Tayvan'da yapmış oldukları çalışmada tüketicilerin genellikle mobil reklamlara karşı olumsuz tutum sergiledikleri fakat kendilerinden izin alındığında bu tutumlarının olumlu olacağı sonucuna varılmıştır. Barwise ve Strong (2002)'nin İngiltere'de yapmış oldukları çalışmada ise tüketicilerin izinli mobil reklamlara karşı tutumun olumlu olduğu tespit edilmiştir. Bu çalışmada da Türk tüketicilerinin mobil reklamlara karşı tutumlarının olumlu olduğu sonucuna varılmıştır. Yapılan çalışmalar sonucunda ülkeler arası farklılıklar görülmektedir. Bu farklııkların da tüketicilerin sosyo-kültürel yapıları ve demografik özellikler gibi değişkenlerden kaynaklandığı ileri sürülebilir.

Alan taraması yapıldığında daha önce mobil reklamlara yönelik tutumun anlık satın alma davranışına etkisini belirlemek amacıyla yapılan herhangi bir çalışmaya rastlanılmamıştır. Bu da bu çalışmanın özgün olduğu göstermektedir. Çalışma basit tesadüfi örnekleme yoluyla mobil telefon kullanan tüketicilere yapılmıştır. Zaman ve maliyet kısıtından dolayı 395 tüketiciye ulaşılmıştır. Bu nedenle çalışma sonuçları hakkında genelleme yapılamaz. Ancak farklı örneklem grupları üzerinde çalışmalar yapılarak genel sonuçlara ulaşılabilir.

Sonuç olarak, günümüz rekabet ortamında işletmelerin aktif olarak kullandığı mobil reklamların etkinliğinin arttırılabilmesi için mesajların içeriğinin bilgilendirici ve dikkat çekici olması gerekmektedir. Tüketicilerin reklam mesajlarına karşı tutumlarının olumlu olması anlık satın alma davranışını etkilemektedir.

\section{KAYNAKLAR}

Altug, N., Yuruk, P. (2013). 2000-2011 yılları arasında tüketicilerin mobil reklamlara olan tutumlarını incelemeye yönelik yapılan araştırmalar. Dokuz Eylül Üniversitesi Sosyal Bilimler Enstitüsü Dergisi, 15 (1), 11-28.

Altunisik, R., Coskun, R., Bayraktaroglu, S., Yildirim, E. (2010). Sosyal Bilimlerde Araştırma Yöntemleri SPSS Uygulamalı (Geliştirilmiş 6. Baskı). Sakarya: Sakarya Yayıncılık.

Altunisik, R., Ozdemir, S., Torlak, O. (2002). Modern pazarlama (Geliştirilmiş 2. Baskı). İstanbul: Değişim Yayınları. 
Arslan, B., Dursun, T. (2015). Türk tüketicilerinin mobil reklamlara yönelik tutumları. Electronic Journal of Vocational Colleges, Aralık, 9-19. Arslan, I. K., Arslan, P. (2012). Mobil Pazarlama-Solomo, (1 Baskı). İstanbul: Papatya Yayıncılık.

Barwise, P., Strong, C. (2002). Permission- based mobile advertising. Journal of Interactive Marketing, 16 (1), $14-24$.

Bayley, G., Nancarrow, C. (1998). Impulse purchasing: a qualitative exploration of the phenomenon. Qualitative Market Research: An International Journal, 1(2), 99-114.

Beatty, S. E., Ferrell, M. E. (1998). Impulse buying: modelling its precursors. Journal Of Retailing, 74 (2), $169-191$.

Boz, M., Karakas, E. (2014). Türkiye'de tüketicilerin mobil reklama yönelik tutumları. Bartın Üniversitesi i.i. B.F. Dergisi, 5 (10), 1-20.

Cakir, F., Cakir, M., Ciftci, T. E. (2010). Tüketicilerin sms reklam mesajlarına yönelik tutum ve davranışları. Organizasyon ve Yönetim Bilimleri Dergisi, 2(1), 27-35.

Collu, E. F., Ozturk, Y. E. (2006). Örgütlerde inançlar-tutumlar tutumların ölçüm yöntemleri ve uygulama örnekleri bu yöntemlerin değerlendirilmesi. Selçuk Üniversitesi Sosyal Bilimler Meslek Yüksekokulu Dergisi, 9 (1-2), 373-404.

Durucasu, R. R., Ersoy, F. (2016). SMS reklamları ve mobil bilgi servislerine yönelik tüketici tutumunu belirleyen bir araştırma. Aksaray Üniversitesi Iktisadi ve İdari Bilimler Fakültesi Dergisi, 8 (2), 1-13.

Erdem, S., Turkyilmaz, C. A., Kirgiz, A. C. (2015). Online anlık satın alma davranışlarının hazcı alışveriş motivasyonları ile açıklaması: hazır giyim ürünleri üzerine bir araştırma. Beykoz Akademi Dergisi, 3(2). 55-74.

Haghirian, P., Madlberger, M. (2006). A cross-cultural analysis of perceptions of mobile advertising- a survey among Austrian and Japanese students. Research Paper, 1(11), 1-12.

Islamoglu, A. H., Altunisik, R. (2010). Tüketici davranışları (3. Baskı). İstanbul: Beta Yayıncılık.

Islamoglu, A. H., Alniacik, U. (2014). Sosyal bilimlerde araştırma yöntemleri (Gözden Geçirilmiş ve Genişletilmiş 4. Baskı). İstanbul: Beta Basım.

Kalaycı, S. (Ed.). (2010). SPSS uygulamalı çok değişkenli istatistik teknikleri (5. Baskı). Ankara: Asil Yayın Dağıtım.

Michael, A., Salter, B. (2006). Mobile marketing (1st Edition). New York: Butterworth-Heinemann.

Peng, B. (2006). Mobile marketing - The Chinese perspective. International Journal of Mobile Marketing, 1 (2), 50-59.

Pride, W. M., Ferrell, O. C. (2000). Marketing concepts and strategies. USA: Houghton Mifflin Company.

Piron, D. (1991). Defining impulse purchasing. Advances in Consumer Research, 18, 509-513.

Robbins, S. P., Judge, T. A. (2012). Örgütsel davranış (14. Basımdan Çeviri), (Çev. Ed. İnci Erdem). İstanbul: Nobel Yayınevi.

Rook, D. W., Hoch, S. J. (1985). Consuming impulses, Hirschman, E. C. ve Holbrook, M. B. (Eds.), Advances in Consumer Research, 12. Ann Arbor: Association for Consumer Research.

Rook, D. W. (1987). The buying impulse. Journal of Consumer Research, 14, 189- 199.

Rook, D. W., R. J. Fisher (1995). Normative influences on impulsive buying behavior. Journal of Consumer Research, 22, $305-313$.

Scharl, A., Dickinger, A. ve Murphy, J. (2005). Diffusion and success factors of mobile marketing. Electronic Commerce Research and Application, 4, 159-173.

Severin, W. J., Tankard, J. W.(2001). Communication theories origins: methods and uses in the mass media (5th Ed.). New York: Longman.

Suher, H. K., Ispir, N. B. (2009). Türkiye'de SMS reklamları: tüketici tutumlarını etkileyen faktörler. Selçuk Üniversitesi Sosyal Bilimler Enstitüsü Dergisi, 21,447-459.

Torlak, O., Tiltay, M. A. (2010). Anlık satınalma ölçeklerinin Türk tüketicisi için uyarlanmasına yönelik bir deneme. 15. Ulusal Pazarlama Kongresi, 405-422.

Trappey, R. J., Woodside, A. G. (2005). Consumer responses to interactive advertising campaigns coupling short-message-service direct marketing and TV commercials. Journal of Advertising Research, 45 (4), 382-401.

Tsang, M. M., Ho, S. C., Liang, T. P. (2004). Consumer attitudes toward mobile advertising: an empirical study. International Journal of Electronic Commerce, 8 (3), 65-78.

Usta, R. (2009). Üniversite öğrencilerinin mobil reklamcılığa karşı tutumları. Doğuş Üniversitesi Dergisi, 10 (2), $294-309$.

Virvilaite, R., Saladiene V., Zvinklyte, J. (2011). The impact of external and Internal stimuli on impulsive purchasing, Economics and Management, 16, 1329-1336.

Yalman, S. (2014). Süpermarket ve hipermarketlerde gerçekleştirilen promosyon çalışmalarının tüketicilerin anlık satın alma davranışlarına etkisi: İzmir ilinde bir araştırma (Yayınlanmamış Yüksek Lisans Tezi). Manisa: Celal Bayar Üniversitesi Sosyal Bilimler Enstitüsü. 
Yuan, S. T., Cheng, C. (2004). Ontology-based personalized couple clustering for heterogeneous product recommendation in mobile marketing. Expert Systems with Applications, 26 (4), 461-476.

Yuce A., Deniz, A., Godekmerdan, L. (2012). Tüketicilerin mobil pazarlama faaliyetlerini benimemesi: üniversite öğrencileri üzerine bir araştırma. Süleyman Demirel Üniversitesi İktisadi ve İdari Bilimler Fakültesi Dergisi, 17 (1), 181-198.

Xu, D. J., Liao, S. S., Li, Q. (2008). Combining empirical experimentation and modeling techniques: a design research approach for personalized mobile advertising applications. Decision Support Systems, 44 (3), 710-724.

https://www.btk.gov.tr/File/?path=ROOT\%2f1\%2fDocuments\%2fSayfalar\%2fPazar_Verileri\%2f2017-Q3.pdf (Erişim tarihi 27/12/2017).

https://www.mmaturkey.org/single-post/2017/05/04/2016-Mobil-Reklam-Harcama-Raporu (Erişim tarihi 02/12/2017). 